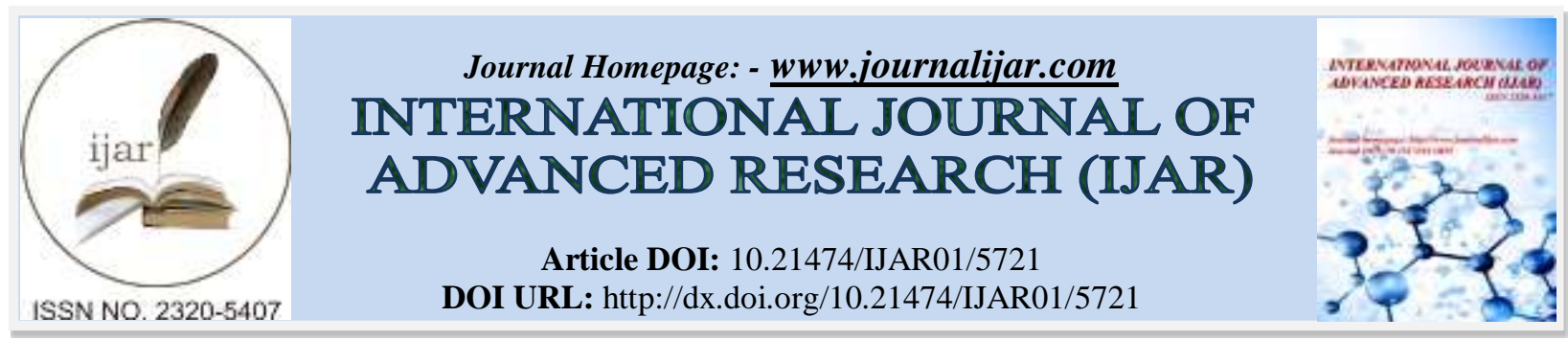

RESEARCH ARTICLE

\title{
A NEW SPECIES OF ERIOCAULON (ERIOCAULACEAE) FROM LATERITIC PLATEAUS OF SINDHUDURD, MAHARASHTRA, INDIA.
}

\section{Paithane V. A ${ }^{1}$, Bhuktar A. S. ${ }^{2}$, Kashetti R. P and Patil S. B ${ }^{3}$.}

1. Dept. of Botany, Anandibai Raorane Arts, Commerce and Science College, Vaibhavwaddi, Dist. Sindhudurg 416810.

2. Dept. of Botany, Vivekanand Arts, S. D. Commerce and Science College, Aurangabad-431002, Maharashtra, India.

\section{Manuscript Info}

\section{Manuscript History}

Received: 25 August 2017

Final Accepted: 27 September 2017

Published: October 2017

Key words:-

Eriocaulon gulnarparianum sp. Nov., Erioculaceae, India, Western Ghats, Maharashtra.

\begin{abstract}
The genus Eriocaulon L. (Eriocaulaceae) is distributed in tropical and subtropical regions of World. Ansari \& Balakrishnan reported 85 species in India, later on 11 species have been described from India and now 96 species recorded for India. During collections from konkan, Western Ghats, India author collected one interesting specimens of Eriocaulon. After critical observation and survey of literature it revealed to be a new species. Eriocaulon gulnarparianum Sp. nov. described which is allied to Eriocaulon xeranthemum Martius and $E$. devendranii Sankar, Ravikumar \& Babu, but differs in its leaf length $0.8 \mathrm{~mm}$ to $1.5 \mathrm{~cm}$, head $5 \mathrm{~mm}$ across with involucrals bracts, without involucral bracts $2 \mathrm{~mm}$ across, floral bracts oblong-oblanceolate, involucral bracts upto $3 \mathrm{~mm}$, acuminate, mulifide. Sepals of male flower obtuse at apex, 3 lobed,2 lobes connate and one free, Petals of female flower spathulate and notched apex, seed with transverse elongated cells with 1-2 appendages which is described with brief morphology, association, photographs and note on identity.
\end{abstract}

Copy Right, IJAR, 2017,. All rights reserved.

\section{Introduction:-}

The genus Eriocaulon is monotypic genus of family Eriocaulaceae. Linnaeus (1753) reported only four species (Three from India), later on in $19^{\text {th }}$ century, (Brown,1810; Martius 1832; Wallich,1832; Royle,1839,Kunth 1841; Dalzell,1851; Griffith,1851; Steudel 1854-1855,Koenick 1856 \& 1867 described number of new species from India. In British India, Hooker (1893) given accounts 43 species of which 14 new species. Ruhland (1903) in monographic study shows 47 species from India. Fyson (1919-1922) described 51 species and few varieties for British India. Ansari and Balakrishanan (1994 \& 2009) in the revisionary study reported 85 species. Later on Yadav et al. 1998, 2008; Shimpale et al.2009; Vijaysankar et al. 2006; Shimpale \& Yadav, 2010; Vivek et al.2010, Namphy et al., 2011, Punekar et al 2002; Punekar \& Lakshaminarsimhan 2004; Punekar et al 2004, Swapna et al., 2012, Sunil \& Naveen Kumar, 2015, Naveen Kumar et al., 2017, Sunil \& Pradeep, 2003, Gaikwad \& Yadav, 2002, Gaikwad et al., 2002, and many others added new species for India, till date 96 species reported for India.

While exploring lateritic plateaus of konkan regions, author collected an interesting specimens from plateaus of Achirne Village, Salva plateaus, and hills slopes in Vaibhavwadi Village of Sindhudurg in Maharashtra and After critical study and comparison with other species of Eriocaulon and scrutiny of literature, it turned out to be quite 
different taxa from known species hence we describe these collection as a new species. The new species is closely allied to Eriocaulon xeranthemum Martius a species common throughout India, Myanmar, Nepal and E. devendranii Sankar, Ravikumar \& Babu, a species endemic to Western Ghats, Kerala

\section{Taxonomy:-}

Eriocaulon gulnarparianum Paithane, Bhuktar A.S., Kashetti R.P. \& Patil S.B. sp.nov.(Fig.1 A-F \& Fig.2 a,b,c.)

Eriocaulon gulnarparianum is similar to Eriocaulon xeranthemum Martius and E. devendranii, but differs from the former in having leaf length $0.8 \mathrm{~mm}$ to $1.5 \mathrm{~cm}$ ( upto $1 \mathrm{~cm}$ in E.devendranii), head $5 \mathrm{~mm}$ across with involucrals bracts, without involucral bracts $2 \mathrm{~mm}$ across, floral bracts oblong-oblanceolate (oblanceolate in E. devendranii), involucral bracts upto $3 \mathrm{~mm}$, acuminate, mulifide (spreading in E. xeranthemum). Sepals of male flower obtuse at apex (Truncate in E. xeranthemum), 3 lobed, 2 lobes conate and one free (three lobed, in E. xeranthemum and $E$. devendranii), Petals of female flowers are spathulate and notched apex (unnotched in $E$. devendranii and $E$. xeranthemum), seed with transverse elongated cells with 1-2 appendages (2-4 in E.devendranii and E.xeranthemum). Type:- India, Maharashtra,Sindhudurg, $13^{0} 43.509^{\prime}$ N,79019.345E, $80 \mathrm{~m}$ elevation, $10^{\text {th }}$ August 2016, Gulnarpari Patankar and Paithane V.A, Kashetti R. P. and Patil. S. B.1044 (Holotype VH!; isotype BSI, CAL)

Acaulescent herb. Root sock absent. Leaves rosulate, linear, acute, $0.8-1.5 \mathrm{~cm}$ long. Peduncles $3-15$, up to $3 \mathrm{~cm}$ long, glabrous, virgate. Sheath $0.5-1 \mathrm{~cm}$ long, glabrous; limb ovate, acute, entire. Head hemispherical or cuneate, ca $5 \mathrm{~mm}$ across with involucral bracts, $2 \mathrm{~mm}$ across without involucral bracts, straw-coloured. Receptacles convex, glabrous. Involucral bracts erect, not spreading, linear-oblong, acuminate, $2.5-3 \mathrm{~mm} \times 0.2-0.5 \mathrm{~mm}$, chartaceous, glabrous, straw coloured. Floral bracts oblanceolate, obtuse, sparsely hoary at apex, 0.5-0.7 x 0.2-0.3 mm. Male flowers: Pedicel minute. Sepal 3, obovate, 2 lobes connate into spathe and one free ca 0.9-1.2 x 0.5-0.7 mm; lobes obtuse, hoary at apex, brown turns black at maturity, stipe of corolla $1 \mathrm{~mm}$ long. Petals 3 , minute, equal, acute to sub-acute, with black gland. Anthers 6, black. Female flowers: Sub-sessile, sometimes with short pedicel. Sepals 3, free, two lateral one oblanceolate, obtuse, sparsely hairy at apex, ca $1 \mathrm{~mm}$ x $0.2 \mathrm{~mm}$; middle one linear, ca $1 \mathrm{~mm} x$ $0.1 \mathrm{~mm}$, sparsely hairy at apex. Petals 3, sub-equal, spathulate, one to two petal notched at apex, 0.5-0.7-0.8-1.2 mm long, hyaline, barbet with black gland. Stipitate between sepals and petals. Ovary sessile, ovoide; style 3 -fid. Seed oblong-ellipsoide, acute at base, obtuse at apex, $0.5 \times 0.2 \mathrm{~mm}$, pale yellow; cells of seed coat transversely elongated, aligned in vertical rows; appendages 1-2 from transverse radial wall, settiform, dilated at apex.

\section{Etymology:-}

The new species named after my under graduate student Gulnarpari Patankar for his valuable collection during exploration and for proving specimens from various localities of Sindhudurg District of Maharashtra State..

Phenology:-Flowering and fruiting in August to October.

\section{Distribution and Ecology:-}

Eriocaulon gulnarparianum is currently known from Achirne, Salva plateaus and hills slopes of Vaibhavwadi villege, Sindhudurg District in Maharashtra State. It grows on lateritic plateaus and wet rocky hillside, in association with Utricularia reticulata, Glyohochloa acuminata, Fimbristylis tetragona, Eriocaulon eurypeplon, Indopoa paupercula, Danthonidium gammiei, Drosera indica, Trithuria konkanensis, Euphorbia concanensis, Exacum lawii, Eragrostis sp., oldenlandia sp.

\section{Conservation Status:-}

Achirne and Salva Plateaus are not thoroughly explored therefore we assess the new species and uncontrolled grazing on Salva and mining at Achirne are added impacts of habitat destruction, hence its necessary to conserve these ecosystem.

Table 1:- Diagnostic morphological characters of Eriocaulon gulnarparianum sp. nov. and allied species.

\begin{tabular}{|c|c|c|c|c|}
\hline Sr.No & Characters & E. devendranii & E.gulnarparianum sp. nov. & E. xeranthemum \\
\hline 1 & Involucral bracts & $\begin{array}{c}\text { Upto } 3.5 \mathrm{~mm}, \\
\text { acuminate, multifide }\end{array}$ & $\begin{array}{c}\text { Up to } 3 \mathrm{~mm} \text {, acuminate, } \\
\text { multifide }\end{array}$ & $\begin{array}{c}\text { 2-3.5 mm long, } \\
\text { Spreading }\end{array}$ \\
\hline 2 & Floral bracts & Oblanceolate & Oblong-oblanceolate & Truncate \\
\hline 3 & $\begin{array}{c}\text { Sepals in Male } \\
\text { flower }\end{array}$ & $\begin{array}{c}\text { Obtuse at apex, } 3 \\
\text { lobed, }\end{array}$ & $\begin{array}{c}\text { Obtuse at apex, 3 lobed, } 2 \\
\text { lobes connate, one free, } \\
\text { slightly jointed at base }\end{array}$ & Truncate, 3 lobed \\
\hline
\end{tabular}




\begin{tabular}{|c|c|c|c|c|}
\hline 4 & $\begin{array}{c}\text { Petals in Female } \\
\text { flowers }\end{array}$ & Spathulate & $\begin{array}{c}\text { Spathulate, one-two petal with } \\
\text { notch }\end{array}$ & Spathulate \\
\hline 5 & Seed Appendages & $2-4$ & $1-2$ & $2-4$ \\
\hline
\end{tabular}

Distribution of allied taxa:-

Eriocaulon xeranthemum Martius is common in open moist or marshy lands and in crevices of moist rock from sea level to 700 altitude, known from Maharashtra, Kerala, Karnataka, Andaman and E. devendranii Sankar, Ravikumar \& Babu (2006) is rare on exposed moist soil and endemic to Western Ghats of Kerala where as described new species is rare on lateritic plateaus of Konkan, Sindhudurg District of Maharashtra State and easily identified by its notched petals of female flower which is distinct characters as compared to all Indian Eriocaulon species.

\section{Acknowledgements:-}

The authors are very much thankful to R. Ansari, Malabar Botanical Garden, Kozhikode, Kerala for his comments and Vijayasankar Raman, National Center for Natural Products Research, The University of Mississippi, USA for providing pictures of Eriocaulon devendranii for comparison. I also Thankful to Dr. Kanchi Gandhi, Harvard University Herbaria, Harvard University, Cambridge, USA for nomenclature of described of species and Principal, Anandibai Raorane Arts, Commerce and Science College Vaibhavwadi, Sindhudurg for Laboratory facilities. I thankful to Head, Dept of Physics, Shivaji University Kolhapur for providing SEM facility.

\section{References:-}

1. Ansari, R \& Balakrishnan, N. P. 1994 The family Eriocaulaceae in India, Bishen Singh Mahendra Pal Singh, Dehra dun

2. Ansari, R \& Balakrishnan, N. P. 2009 Revised by R. Ansari The family Eriocaulaceae in India, Bishen Singh Mahendra Pal Singh, Dehra dun

3. Brown, R. 1810 Prodromus Florae Novae Hollandiae et insulae van- Diemen.- Facsimile edition: Weinhelm 1960

4. C. N. Sunil \& V. V. Naveen Kumar 2015 A New Species of Eriocaulon (Eriocaulaceae) from Western Ghats, India Journal of Plant Taxonomy and Geography 70:20, 211-215.

5. C. N. Sunil, M. K. Ratheesh Narayanan, M. K. Nandakumar, Sujata K. A., Jayesh P. Joseph and N. Anil Kumar 2013 Eriocaulon Kannurense (Eriocaulaceae) A New Species from Kerala, India. International Journal of Plant , animal and Environmental Science vol. 3(2)116-120.

6. C.N. Sunil \& V.V. Naveen Kumar 2015 A new species of Eriocaulon (Eriocaulaceae) from Western Ghats, India Webbia_Vol. 70 (2) 211-215.

7. Dalzell, N. A 1851. Eriocaulon rivulare.- Hooker's J. Bot. kew Gard. Misc. 3:280.

8. Fyson, P. F. 1919-1922. The Indian Species of Eriocauln.- J. Indian Bot. 1:51-55, 2:133-150, 192-207, 259-266, 307-320, 3: 12-18, 91-115.Griffith, W. 1851 Nayulae Ad Plantas Asiaticas. Part III. Calcutta.

9. Gaikwad, S. P., M. M. Sardesai and S. R. Yadav. 2002. A new species of Eriocaulon L. (Eriocaulaceae) from Maharashtra, India. Rheedea 12: 133 - 136.

10. Gaikwad, S.P. and S.R. Yadav. 2002. Eriocaulaceae in Maharashtra. In: Pullaiah, T. (Ed), Biodiversity of India 1: 256-341. Regency Publications, New Delhi.

11. Gaikwad, S.P., M. M. Sardesai, U. S. Yadav and S. R. Yadav. 2004. A new species of Eriocaulon L. (Eriocaulaceae) from Karnataka, India. Rheedea 14: 63 - 65.

12. Griffith, W. 1851. Natulae Ad Plantas Asiaticas. Part. III Calcutta.

13. Hooker, J. D. 1893. Eriocaulaceae.- flora of British India. 6: 571-585. London.

14. Koernicke F. A. 1867. Eriocaulaceae. In Miquel, F.A.W.-Annales Musei Botanici Lugduno-Batavi. Vol. 3. P. 162-164, 238-241, Amsterdam.

15. Koernicke, F. A. 1856 Monographiae Eriocaulacerum Supplementum.- Linnaea 27: 561-692.

16. Kunth, C. S. 1841 Enumeratio Plantarum. Vol. 3 Stuttgart.

17. Linnaeus, C. 1753. Species Plantarum. Vol. 1. Stockholm.

18. M. M. Swapna, K. P. Rajesh, C. N. Manju, R. Prakashkumar 2012 Eriocaulon madayiparense (Eriocaulaceae) - A new species from the foot hills of the Western Ghats of India PhytoKeys 10: 19-23

19. Martius, C. F. P. 1832. Eriocauleae et xyrideae Indae Orientalis.- In Wallich, N. -Plantae Asiaticae Rariores. Vol. 3 p. 27-30. London.

20. Nampy S, Manudev K. M, Pradeep A. K. (2011) Two new species of Eriocaulon (Eriocaulaceae) from India. Edinburgh J. Botany 68: 257-263. 
21. P. Biju, K. Subramanya Prasad, P. Ajith Kumar, Jomy Augustine, K. Raveendran and R. Ansari 2012 Eriocaulon cheemenianum (Eriocaulaceae) a New Species from Kerala, India, International Journal of Plant, Animal and Environmental Science vol. 2(4) 176-179.

22. Pradeep, A.K. and C.N. Sunil. 2003. Eriocaulon ansarii Pradeep \& Sunil (Eriocaulaceae), a new species from India. Candollea 58: 321-323.

23. Punekar, S. A. and. Lakshminarasimhan, P. 2004. Eriocaulon peninsulare (Eriocaulaceae) - a new species from India. Nord. J. Bot. 23: 173 - 175.

24. Punekar, S. A., Lakshminarasimhan, P. \& Vasudeva Rao, M. K. 2002 Eriocaulon balakrishanii (Eriocaulaceae), A new species from the Western Ghats of India- Nord. J. Bot. 22 (5): 609-611.

25. Punekar, S. A., N. V. Malpure and P. Lakshminarasimhan. 2003. Five new species of Eriocaulon L. (Eriocaulaceae) from the Western Ghats, India. Rheedea 13: 19 - 27.

26. Punekar, S. A., N. V. Malpure, and P. Lakshminarasimhan. 2004. Three new species of Eriocaulon L. (Eriocaulaceae) from Peninsular India. Sida 21: $625-635$.

27. Royle, J. F. 1839. Eriocaulaceae.-In: Illustration of The Botany and other Branches of the Natural History of Himalayan Mountain and of the Flora of Cashmere. Vol. 1 P. 409. London.

28. Ruhland, W. 1903, Eriocaulaceae-In: Engler, A. - Das Pflanzenreich. 13. Heft. IV. 30.

29. Shimpale V. B., Bhagat R. B., Deshmukh R. B., Yadav S. R. (2009) A new species of Eriocaulon (Eriocaulaceae) from Maharashtra, India. Rheedea 19 (1 \& 2): 47-49.

30. Shimpale V. B., Yadav S.R. 2010 Eriocaulon belgaumensis: a new species of Eriocaulaceae from the Western Ghats of India. Kew Bulletin 65 (2): 337-339

31. Shimpale, V.B., R. B. Bhagat, R. B. Deshmukh and S.R. Yadav. 2009. A new species of Eriocaulon L. (Eriocaulaceae) from Maharashtra, India. Rheedea 19: $47-49$.

32. V. V. Naveen Kumar, C. N. Sunil, C. R. Remya Krishnan, M. G. Sanilkumar \& E. C. Baiju $2017 \underline{\text { A new species }}$ of Eriocaulon (Eriocaulaceae) from Southern Western Ghats, Kerala, India Webbia Vol.

33. Vijayasankar, R., K. Ravikumar and N.M.G. Babu. 2006. A new species of Eriocaulon L. (Eriocaulaceae) from Anamalai Hills of Kerala, India. Rheedea 16: 59 - 61.

34. Vivek, C. P., M. M. Swapna, and K. K. Suresh. 2010. Eriocaulon wayanadense (Eriocaulaceae), a new species from Kerala, India. Rheedea 20, 25-27.

35. Wallich, N. 1832. Plantae Asiaticae Rariores. Vol. 3. London

36. Yadav S. R., Potdar G.G, Kumar A.A, Otaghvari M, Sonkar A (2008) Eriocaulon epedunculatum a new species of Eriocaulaceae from the Western Ghats India. Kew Bulletin 63 (3): 503-505.

37. Yadav, S. R., S. P. Gaikwad and M. M. Sardesai. 1998. A new species of Eriocaulon L. (Eriocaulaceae) from India. Rheedea 8: 145 - 147. 